\title{
450 オフセット輪転機に生じる印刷縞の発生メカニズム
}

\author{
Mechanism of Streaking Induced in Offset Printing Machine
}

\author{
○太田智道（早稲田大） \\ 正川本広行 (早稲田大)
}

神山和仁（早稲田大）

Tomomichi OTA, Kazuhito KAMIYAMA and Hiroyuki KAWAMOTO

Dept. of Mechanical Engineering, Waseda University, 3-4-1, Okubo, Shinjuku, Tokyo 169-8555

\begin{abstract}
A print defect of streaking took place in an offset printing machine after ditches of blanket drums collided with those of proof cylinders. The streaking was visible just after the collision. These experimental features suggested that the defect was caused by the vibration of blanket drums and proof cylinders due to the collision of these ditches. This hypothesis was proved by the experiment that the pitch of streaking coincided with the period of the vibration. The experimental results were confirmed by the numerical calculation based on a simple linear vibration model of eight-degree-of-freedom.
\end{abstract}

Key Words: Vibration of Mechanism, Forced Vibration, Simulation, Streaking, Offset Printing Machine

\section{A1. はじめに}

新聞用オフセット輪転機に印刷縞が生じることがある. この印刷縞は各胴にブランケットや版を取り付けるための 溝が衝突した直後に数本生じ, その後は急激に減衰消滅す る.このことより, 溝が衝突した際にブランケット胴が過 渡振動し，紙にかかる印圧が交番的に変化するために印刷 縞が生じると考えられる.これを検証するために本研究で は，印刷縞の画像処理により印刷濃度の空間分布を求め, 各胴の振動を測定し，印刷縞と振動の相関関係を調べた。 また,シミュレーションによって実験結果を再現した。

\section{A2. 画像解析}

印刷縞の特徴を定量化するために, 印刷画像をスキャナ で読み込んだ後 PCで 2 值化処理した (Fig. A1). なお各回 転数における (a), (b) はそれぞれブランケット胴の溝同士 (B-B) の衝突後に生じた印刷縞とブランケット胴と版胴の 溝同士 (B-P) の衝突後に生じていた印刷縞である.

(1) ブランケット胴と版胴の溝が衝突した後よりも，ブラ ンケット胴同士の溝が衝突した後のほうが縞の発生が 顕著である。

(2) 回転数が高くなるほど印刷濃度のコントラストは小さ くなる。

(3) ブランケット胴の溝同士の衝突による印刷縞の卓越周 波数とブランケット胴と版胴の溝同士の衝突による印 刷縞の卓越周波数はほぼ一致している。

\section{A3. 振動解析}

Fig. A2 に示すような輪転機の印刷部を 4 質点で各 $x, y$ 方 向の自由度を有する線形 8 自由度系で近似した。このモデ ルに対して, 固有值解析と衝擊振動応答の数值計算を行い, 以下の結論を得た。
(1) 印刷縞は各胴の溝の衝突により対のブランケット胴が 逆相に振動し, 紙にかかる印圧が交番的に変化するた めに生じる.

(2) 導出した振動方程式から計算した固有値, 衝撃振動応 答ともに実測值をほぼ再現した。
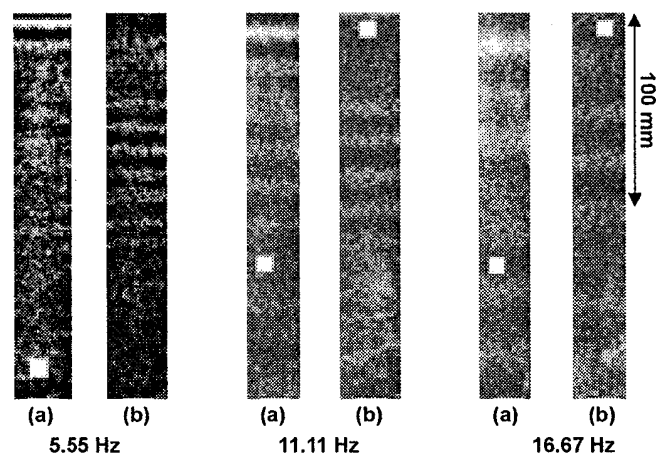

11.11 $\mathrm{Hz}$

Fig. A1 印刷紙面の印刷縞の 2 值化画像

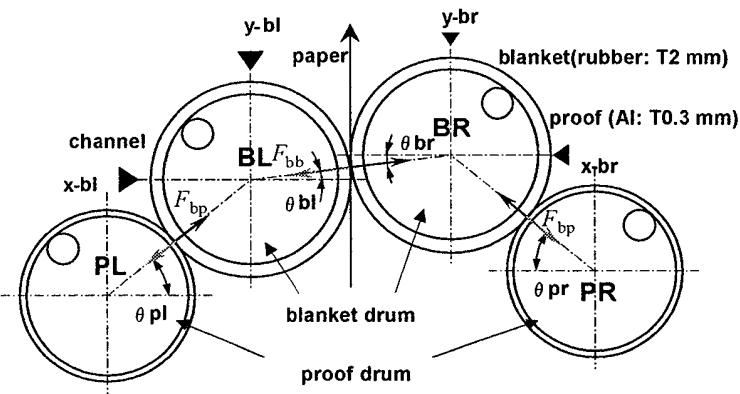

Fig. A2 オフセット印刷機のブランケット胴と版胴 


\section{1. 緒言}

新聞や雑誌などを大量に印刷するための機械として，オ フセット輪転機が広く使用されている，オフセット輪転機 の印刷部はシアン，イエロー，マゼンタ，クロの各色に対 して 2 対の刷版を巻く版胴，印刷紙にインクを転写するた めに表面が:ジム製であるブランケットを巻くブランケット 胴とその周りに配置されているインクシリンダーから構成 されている.

従来のオフセット輸転機の版胴とブランケット胴は, 印 刷紙面の 2 倍の周長があり，そのため使用されるアルミ製 版とブランケットの長手方向の長さも印刷対象の 2 倍必要 である。そこで消耗品である版とブランケットの節約を目 的として，版胴とブランケット胴の周長を印刷対象と同じ にする小径オフセット輪転機が開発された。しかしこのよ うなブランケット胴と印刷版胴を小径化した新聞用オフセ ット印刷機には印刷縞 (streaking) が生じることがある。こ の印刷縞の発生条件と特徵は以下のようであることが報告 されている。

(a) ブランケット胴と印刷版胴には，それぞれゴム製のブ ランケットとアルミ製の刷版を取り付けるための溝が 設けられているが，印刷縞は，ブランケット胴同士， およびブランケット胴と版胴の溝が衝突後に生じる。

(b) ブランケット胴と版胴の溝が衝突した後よりも，ブラ ンケット胴同士の溝が衝突した後のほうが綂の発生が 顕著である。

(c) 印刷縞は数本であり，急激に減衰消滅する.

(d) 上記の溝をゴムで埋めることによって, 縞の発生が防 げる.

(e) 縞の発生はブランケットの材質にも依存するが，ブラ ンケットのどのような特性が影響するのかは不明であ る。

(f) 印刷縞は，ハーフトーンの印刷に対して顕著である.

(g) 印刷縞の空間周波数は，160〜300 Hz 程度であり， 種々の条件によってばらつく.

(h) 従来の大径胴を用いた印別機ではほとんど生じない.

定性的ながら，以上の観測結果から，印刷縞は，ブラン ケット胴同上，およびブランケット胴と版胴の溝の衝突に よってブラングット胴が過渡振動し，紙にかかる印圧が交 番的に変化することによって生じるのではないかと考えら れる. そこで本報告では，ブランケット胴と版胴からなる 系の振動解析を行い, 実験結果と比較することによって, 印刷縞の発生メカニズムを検討した.

\section{2. 印刷縞}

印刷縞の特徴を定量化するために，印刷画像をスキャナ で読み込んだ後 PCで 2 值化処理した.この画像の一部を 回転数別 $(5.56,11.11,16.67 \mathrm{~Hz})$ に Fig. 1 に示す。な抢各 回転数における (a)，(b) はそれぞれブランケット胴の溝同 士 $(\mathrm{B}-\mathrm{B})$ の衝突後に生じた印刷縞とブランケット胴と版胴 の溝同士 (B-P) の衝突後に生じていた印刷縞である。また 図中の白色正方形は，スケールとして $10 \times 10(\mathrm{~mm})$ の紙片 を付して読み込んだものである. Fig. 2 に各回転数におけ る印刷濃度の空間分布を示す. Fig. 2, Fig. 3 において濃度 值が高いほど白色に近いことを示している．また Fig. 4, Fig. 5 に各回転数における印刷濃度の空間スペクトルを示
す。これらの図から，印刷縞には以下のような特徴がある ことがわかる.

(1) ブランケット胴と版胴の溝が衝突した後よりも，ブラ ンケット胴同士の溝が衝突した後のほうが縞の発生が 顕著である. 特徴 (b) に一致.

(2) 回転数が高くなるほど空間周波数が低い.(縞のピッ チが広い)

（3）回転数上昇にともない印刷濃度の明暗は小さくなる.

(4) ブランケット胴の溝同士の衝突による印刷縞の卓越周 波数とブランケット胴と版胴の溝同士の衝突による印 刷縞の卓越周波数はほぼ一致している.

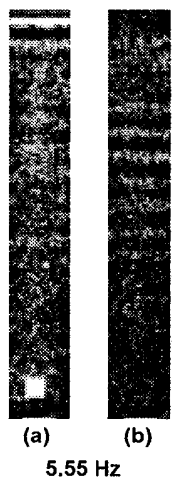

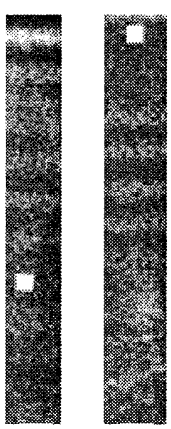

(b)

$11.11 \mathrm{~Hz}$

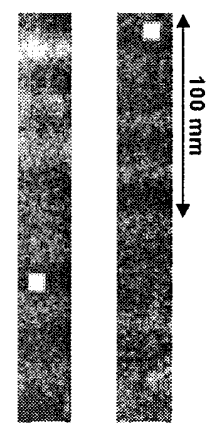

(b)
Fig. 1 印刷紙面の印刷縞の 2 值化画像

(a) ブランケット胴 - ブランケット胴間の溝衝突後の印刷縞

(b) ブランケット - 版胴間の溝衝突後の印刷縞

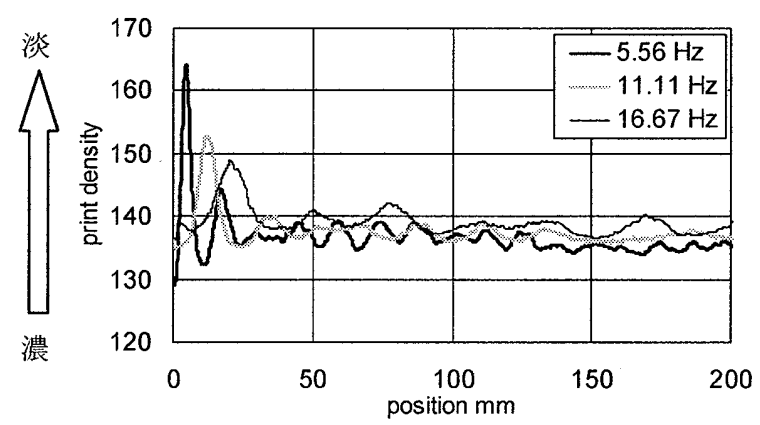

Fig. 2 印刷紙面上の印刷濃度空間分布 (ブランケット胴 -ブランケット胴問の溝衝突後の印刷縞)

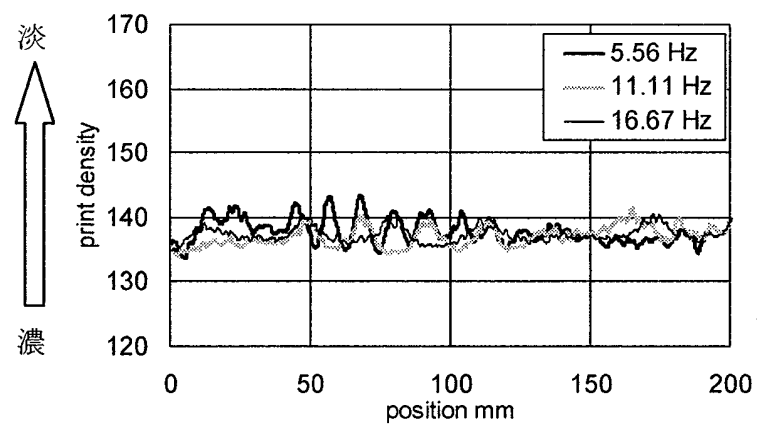

Fig. 3 印刷紙面上の印刷濃度空間分布 (ブランケットー版同間の溝衝突後の印刷縞) 


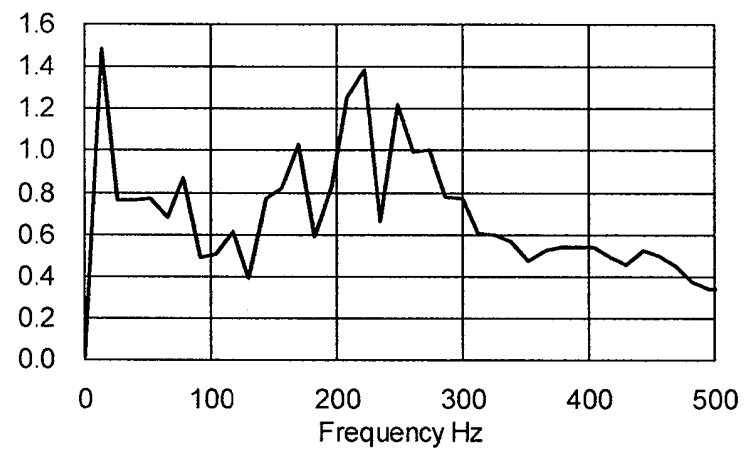

Fig. 4 印刷濃度の空間スペクトル (回転数 $5.56 \mathrm{~Hz}$ ) ブランケット胴 -ブランケット胴間の溝衝突後の印刷縞

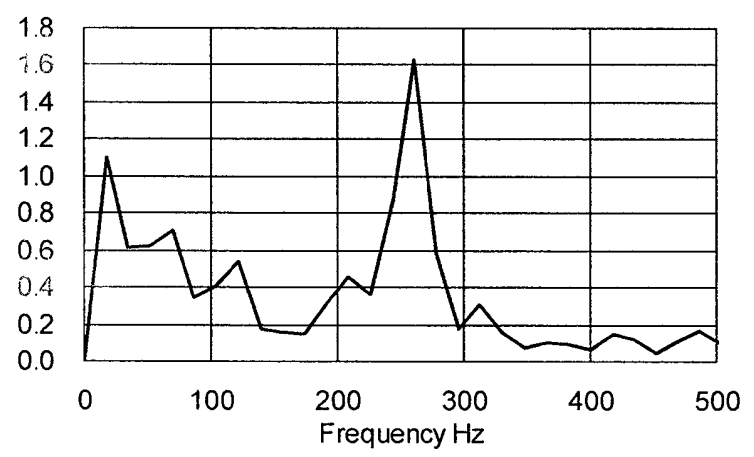

Fig. 5 印刷濃度の空間スペクトル (回転数 $5.56 \mathrm{~Hz}$ ) ブランケット胴 - 版胴間の淒衝突後の印刷縞

\section{3. 振動モデル}

Fig. 6 に示すようなゴム製のブランケットを介して接触 する 2 対のブランケット胴と版胴を Fig. 7 に示すような 4 質点で各 $x, y$ 方向の自由度を有する線形 8 自由度系で近似 寸る，なお，文献 (2)にゴムの粘弾性的な性質によって， 多角形化現象が生じることのあることが報告されているが， 本ブランケットではこのような現象は観測されていない. そこで，本モデルではブランケットを単純なばねーダンパ 系とみなした. Fig. 5 に対応する振動方程式は下記となる.

$$
M \ddot{R}+C \dot{R}+K R=F
$$

ただし， $\boldsymbol{M}$ : 質量マトリクス, $\boldsymbol{C}$ : 隇衰マトリクス, $\boldsymbol{K}$ : 剖性マトリクス, $F$ : 外力ベクトル, $R$ : 変位ベクトルであ る. ブランケットの用性 $k_{b b}, k_{b p}$ はブランケット胴および 版胴の押し込み量 $a$ を用いヘルツ接触によって算出した. 振動衝撃にステップ入力するパルス幅は, ニップ幅 (ブラ ンケット同士の接触長さ) に相当する時間だけ力が加わる ものとし，以下に示す式を用いて求めた。

$$
t=\frac{a}{\pi} \sin ^{-1}\left(\frac{a}{r}\right) \cdot \frac{3600}{\omega}
$$

ただし, $t$ : パルス幅, $a:$ ニップ幅, $r$ :胴の半径, $\omega$ : 回転数である。

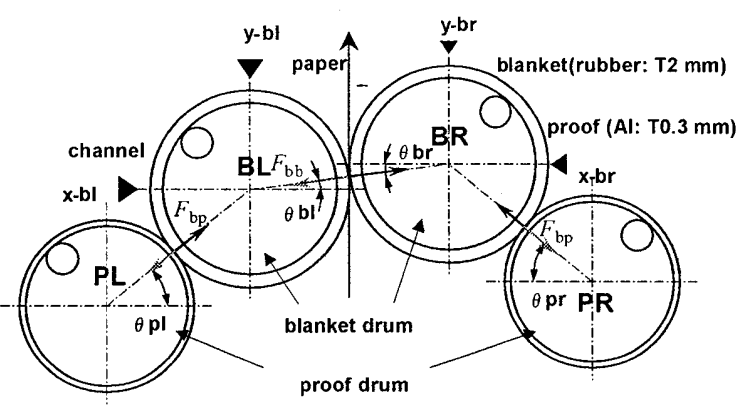

Fig. 6 オフセット印刷機のブランケット胴と版胴

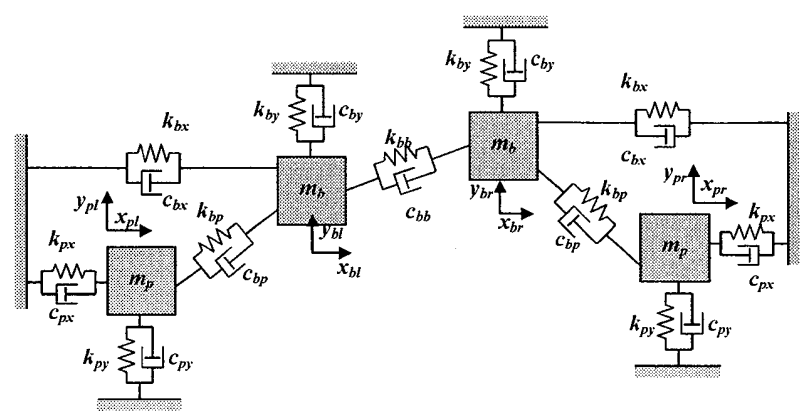

Fig. 7 振動モデル

$$
\begin{array}{lcl}
m & \text { 質 量 } & \\
k & \text { 剛 性 } & \\
& k & \text { ヘルツ接触によるブランケットの岡性 } \\
& k_{b}, k_{p} & \text { ブランケット胴と版胴の軸受・曲げ剛性 } \\
& k_{b p} & \text { ブランケット胴と版胴間のヘルツ接触に } \\
& & \text { よるブランケットの剛性 }
\end{array}
$$

c 減衰

$x, y$ 変位

$$
\begin{array}{rl}
\text { 添字 } b & \text { ブランケット胴 } \\
p & \text { 版胴 } \\
x & x \text { 方向 } \\
y & y \text { 方向 }
\end{array}
$$

\section{4. 振動の計算結果と実測値}

\section{1 ブランケット胴振動測定}

ブランケット胴 ( $(170 / L 140.6)$ の振動が印刷縞を生じる 原因であることを確認するために，Fig. 6 に示すように $x$ - bl, $x$ - $b r, y$ - $b l, y$ - $b r$ の位置に振動センサを計 4 台設置してその 振動を計測した。振動センサは静電容量式センサ VE531 (小野測器, 測定範囲：0 5 mm) を用い, その信号をアナ 口グ式変換器 (小野測器, VT510) によって電圧に変換し変 位量に変換した。測定の結果は, 4.3 項に計算值と対比さ せて示す。

\section{2 固有モードと固有値}

8 自由度振動モデルに対応ずる 8 組の固有モード (無減 衰)の計算結果を Table 2 に示し, 固有振動数と減衰比を Table 3 示す. また, Fig. 8 に印刷紙面上の印刷縞から算出 した卓越周波数と左右のブランケット胴の相対振動 (Xbl - Xbr) の実測值を FFT 解析することによって導出した 卓越数端数を計算による固有振動数と比較して示す. 
Table 2 固有モード計算結果

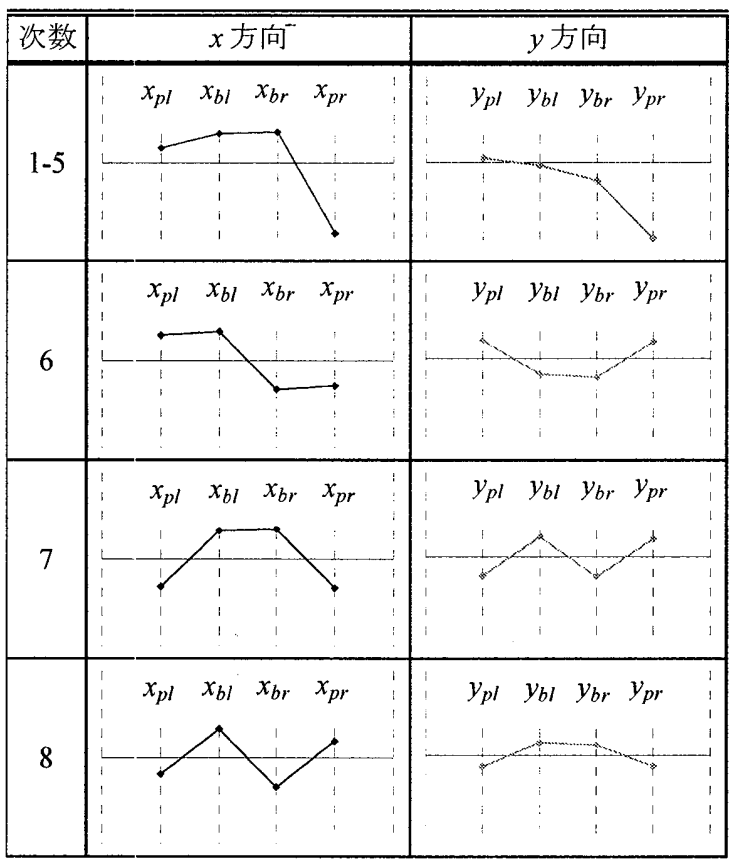

Table 3 固有振動数と減衰比の計算結果

\begin{tabular}{|c|c|c|}
\hline \hline 次数 & 固有振動数 $(\mathrm{Hz})$ & 減衰比 $(\%)$ \\
\hline 1 & 129.81 & 4.68 \\
\hline 2 & 129.85 & 4.85 \\
\hline 3 & 129.87 & 4.53 \\
\hline 4 & 134.57 & 4.52 \\
\hline 5 & 134.73 & 4.51 \\
\hline 6 & 150.35 & 5.49 \\
\hline 7 & 195.80 & 5.46 \\
\hline 8 & 208.65 & 6.36 \\
\hline
\end{tabular}

Table 2 から左右ブランケット胴が逆相に振動する 6 次, もしくは 8 次の固有モードで印刷縞が生じると考えられる.

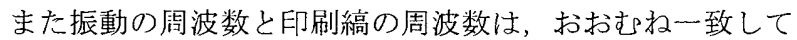
おり，計算值もこれらの実測值に近い。しかし実測值の周 波数は, 振動の周波数と印刷縞の周波数ともに, 明らかに 回転数とともに上昇しているのに対して, 計算では回転数 の効果は考慮されていないため一定である。したがって, 解析でも何らかの方法で回転数の影響を考慮すべきである が，そのひとつとして，表面材質がゴムであるブランケッ 卜の剛性の速度依存を考えた.すなわち, Fig.8における印 刷縞卓越周波数から各回転数でのブランケットの㴊性值を 算出し，その值から最小二乗法を用いて剛性の回転数依存 性を一次式で近似した。 その結果を Fig. 9 に示す。このと きブランケットの剛性 $k_{b b}, k_{b p}$ は式 (3), (4)のようになる.

$$
\begin{aligned}
& k_{b b}=\left(6.871 \times 10^{6}\right) f+\left(3.171 \times 10^{7}\right) \\
& k_{b p}=2 \times k_{b b}=2 \times\left\{\left(6.871 \times 10^{6}\right) f+\left(3.171 \times 10^{7}\right)\right\}
\end{aligned}
$$

式 (3), (4) の剛性值を用いて回転数別に各モードの固有振 動数を計算し実測值と比較した結果を Fig. 10 に示す. 図か ら計算值が実測值をよく再現できていることがわかる，し たがって今後は，ブランケットに現実にこのような効果か あるかどうかを確認する必要がある。

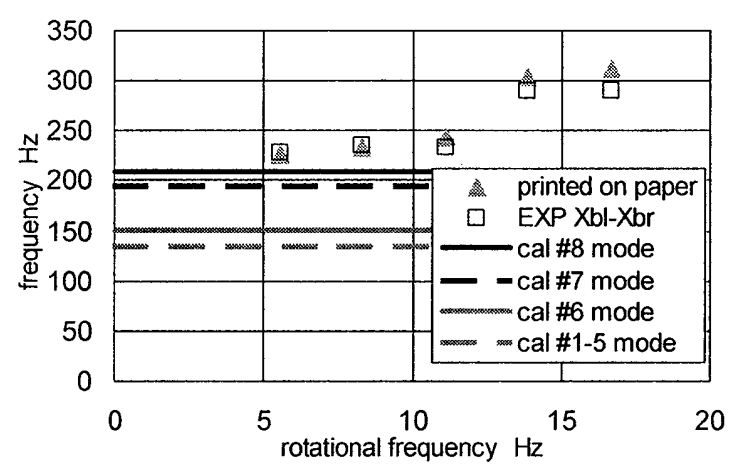

Fig. 8 固有振動数の実測值と計算值 (ブランケットの㓮性が一定の場合)

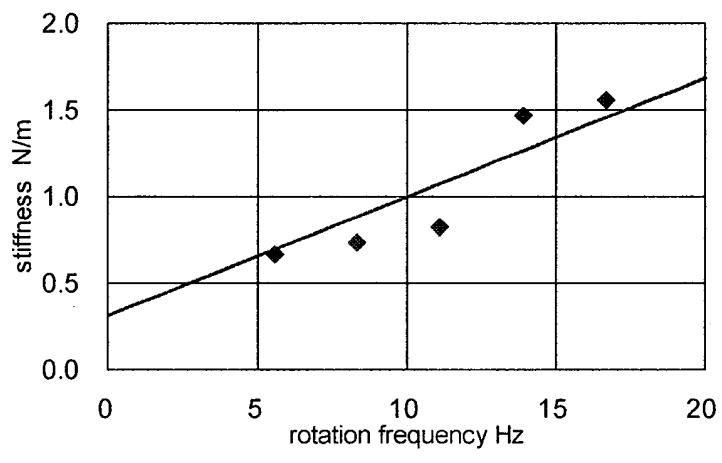

Fig. 9 ブランケット剛性の周波数依存性一次近似

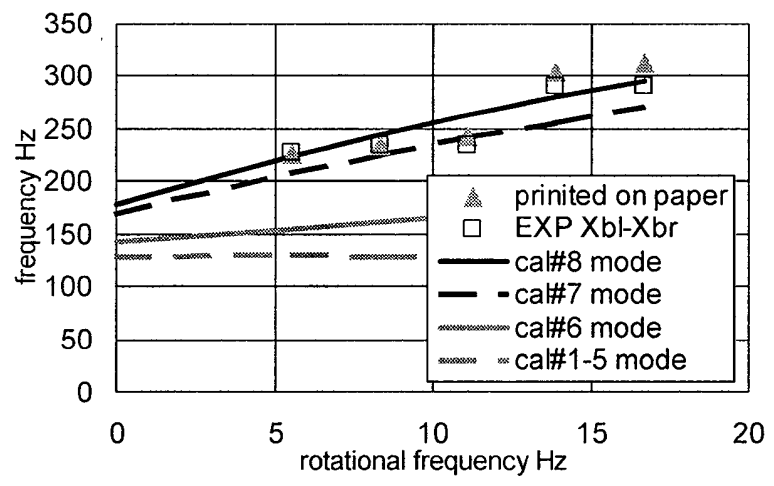

Fig. 10 固有振動数の実測值と計算値 (ブランケット㴊性が式 (3)，(4)の周波数依存性:を有する場合)

4.3 衝撃振動応答

衝撃振動応答の計算結果の一例を Fig. 11 に示す.なおブ ランケットの岡性は式 (3)，(4) を用いた。図から以下のよ うな知見が得られる。

(1) ブランケット胴と版胴，およびブランケット胴同士の 溝部の衝突により，ブランケット胴は過渡衝擊振動し， これは特徴 (a)に一致する。

(2) ブランケット胴と版胴よりもブランケット胴同士の溝 部の衝突による振動のほうが大きく、これは緒言の報 告 (b)に一致する.

(3) 衝撃が加わった後, 左右のブランケット胴の振動は逆 相になる. 

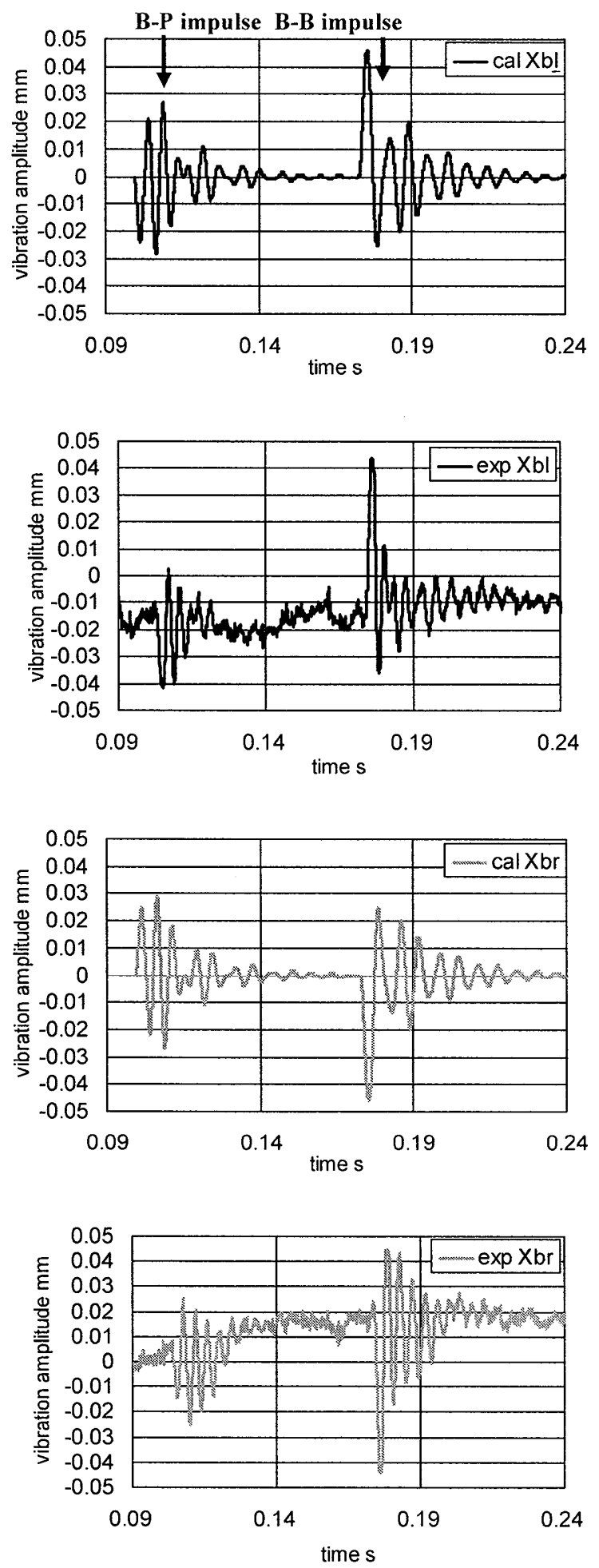

Fig. 11 振動応答の計算值と実測値 $(5.56 \mathrm{~Hz})$

\section{4 印刷縞とブランケット胴の相対振動}

印刷時のブランケット胴間の印圧と直接関係のあるブラ ンケット胴の水平方向振動の相対変位 $(\mathrm{Xbl}-\mathrm{Xbr})$ の計算值 と実測値を比較して Fig. 12 に示す，相対変位の計算值と実 測值はよく一致していることがわかる.

相対変位の実測值と印刷縞の濃淡の比較を Fig. 13 に示す. ただしFig. 13 において印圧抜けが生じるのは相対変位が負
の場合であるので相対変位の軸を反転している．以上の Fig. 12, Fig. 13 から以下の知見が得られる.

(1) 最大振動変位は $80 \mu \mathrm{m}$ 程度である.

(2) 衝突直後に大きな相対変位が生じるが，数サイクル後 には減衰する。実際の印刷縞も衝撃後の数列のみにし か観測されておらずこの計算結果は特徵 (c) に定性的 に一致する.

(3) 回転数が高くなるほど，計算でも実験でも，相対変位 が小さくなる.これはFig. 2, Fig. 3に示すように，回 転数が高くなるほど印刷編のコントラストが小さくな っていることに対応しており，この点でも，ブランケ ット胴の横方向相刘変位が印刷縞の原因であることを 示唆している.また，計算の妥当性を示すものでもあ る.

(4) $x$ 方向の相対変位と印刷繑濃度の空間分布は相対的な 大きさも位相もおおむね一致している。

以上のことから，印刷縞の発生原因がブランケット胴の横 方向の逆相の振動によることが再確認できる.
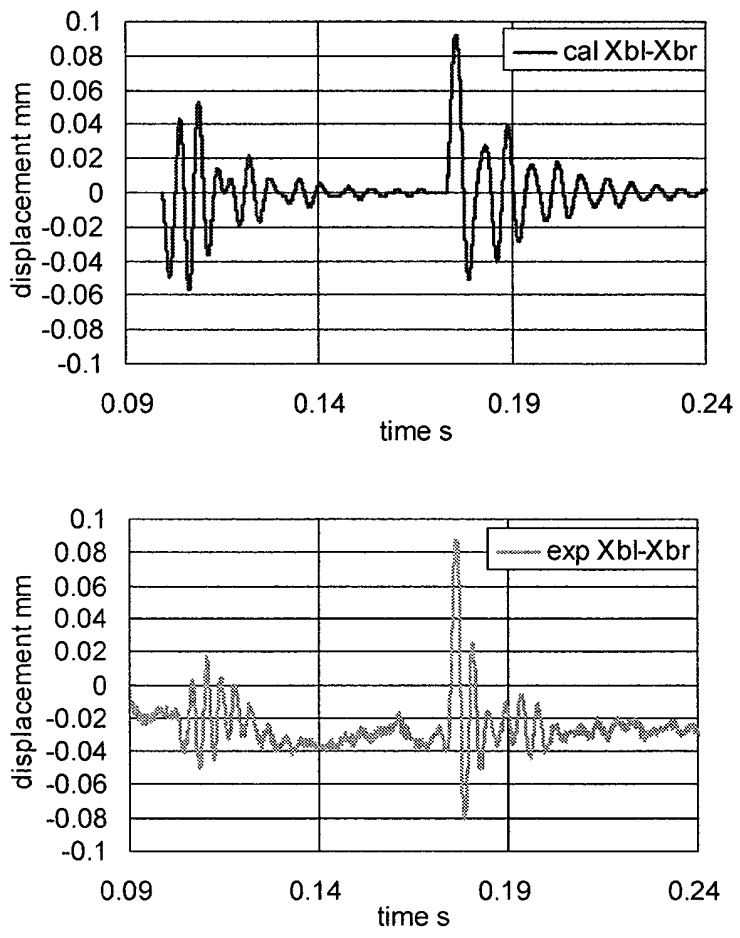

Fig. 12 相対変位の計算值と実測值 $(5.56 \mathrm{~Hz})$

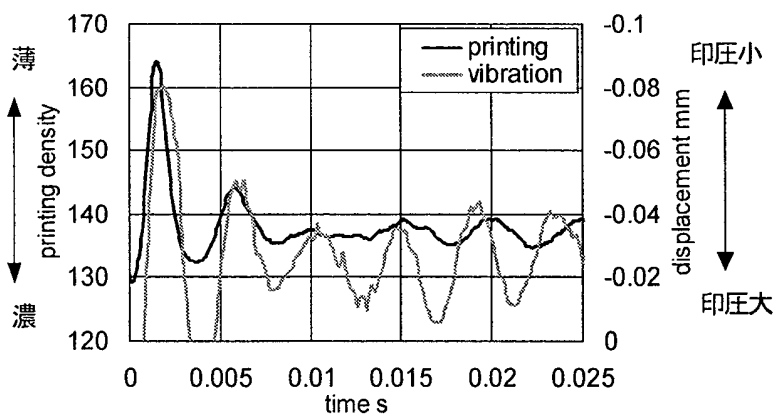

Fig. 13 印刷縞とブランケット胴の相対変位の関係 $(5.56 \mathrm{~Hz})$ 


\section{5. 結言}

ブランケット胴と印刷版胴を小径化した新聞用オフセッ 卜印刷機に生じる印刷縞の発生原因を究明するために, ブ ランケット胴と版胴を簡単な線形 8 自由度モデルで近似し た振動解析を行った。計算結果は定性的にも定量的にもお おむね実験結果に一致した。本研究から推測される印刷縞 の発生メカニズムと振動の特徴は以下のとおりである.

印刷縞の発生メカニズム

(1) ブランケット胴同士抢よびブランケット胴と版胴の溝 が衝突した際に, 水平方向の強制外力が生じ, ブラン ケット胴と版胴が過渡応答振動する。

（2）衝撃力はブランケット胴同士が逆位相に振動する方向 に作用するため，実際の振動もブランケット胴同士が 逆位相に振動するモードが支配的である。

(3) ブランケット胴同士が相対変位することによって紙に 作用寸る印圧も交番的に変化し，これによって印刷縞 が生じる.

印刷縞の発生原因となる振動の特徵

（1）ブランケット剛性の周波数依存性によって，振動の周 波数は，低速時の約 $200 \mathrm{~Hz}$ から高速時の約 $300 \mathrm{~Hz}$ に 上昇する．縞の空間周波数も同様である.
(2) ブランケット胴の相対変位は最大で約 $80 \mu \mathrm{m}$ 程度であ る.

(3) この過渡応答振動は数サイクルで急激に減衰消滅する。

(4) ブランケット胴之版胴の溝が衝突した後の振動振幅よ りも,ブランケット胴同士の溝が衝突した後の振動振 幅のほうが大きく，印刷縞の濃度空間分布もブランケ ット胴同士の衝突後の方が顕著である.

（5）低回転数のほうが振動振幅は大きく，縞の濃淡も大き い.

（6）ブランケットの粘弾性的な性質にともなう多角化現象 は観測されなかった。

本研究の実験データは東京機械製作所に提供していただ いた。深く謝意を表します.

\section{6. 参考文献}

（1）日本機械学会編, 機械工学便覧, 日本機械学会 (1987).

（2）末岡・ほか 7 名，ゴム巻きロールの多角形化現象, 機論 C, Vol. 59, No. 563 (1993) pp.2078-2085. 